\title{
Spatial analysis of the regeneration after fire in forest of Lardjem (Wilaya of Tissemsilt, Algeria)
}

\author{
Tir Elhadj ',", Haddouche Driss', Nouar Belgacem² \& Maamar Benchohra ${ }^{3}$ \\ ${ }^{1}$ Laboratory of Conservation and Management of Water, Soil and Forests Sustainable Mountain Development in the \\ Region of Tlemcen, Aboubakr Belkaid University Tlemcen, Algeria \\ ${ }^{2}$ Laboratory of Ecology and Natural Ecosystems Management, Aboubakr Belkaid University, Tlemcen, Algeria \\ ${ }^{3}$ University of Tiaret, Algeria \\ *Corresponding author, e-mail: imadtir@yahoo.fr
}

\begin{abstract}
The present study aims to characterize the changes that have occurred in the Lardjem forest (Wilaya of Tissemsilt, Algeria) after four years of disastrous fire passage in 2012. The methodological approach adopted is essentially based on the analysis and interpretation of Normalized Difference Vegetation Index (NDVI). The approach is based on the analysis of satellite data into classes taken before and after the fire (1987-2016) associated with field checks. The results, validated against ground-truth data, show a considerable reduction in the forest class with $81.72 \%$ and the maquis class with $48.48 \%$. On the contrary, it has been shown that the area of clear maquis and empty area increased with a rate of $117.11 \%$ and $39 \%$ respectively. The different mutations between the occupancy classes before and after the fire show that the forest stratum of wild Thuja Tetraclinis articulata (Vahl) Mast has recovered its appearance with a very low percentage. This recovery is more significant as soon as the conditions are favorable (northern slope, weak slopes and humidity). The parts covered by the tree stratum are transformed into clear maquis, matorrals and empty soils, these classes can reach a more advanced stage if the zone is moved away to repetitive fires in the coming years. Finally, a repopulation of the empty parts associated with a management and protection plan is necessary to safeguard the perinity of this forest.
\end{abstract}

KEY WORDS Forest fire; GIS; Lardjem; NDVI; Regeneration; remote sensing.

Received 23.02.2021; accepted 03.08.2021; published online 22.11.2021

\section{INTRODUCTION}

Among many attacks, the Algerian forests suffer from human activities threatening their sustainability, fire is considered as one of the most daunting by the losses it causes (Madoui, 2002; Missoumi et al., 2002; Meddour-Sahar et al., 2008; MeddourSahar \& Bouisset, 2013; Talbi et al., 2017).

With an assumed $1 \%$ reforestation rate, but this is unfortunately not the case, forest fires cause a loss of around 15,000 hectares destroyed annually, on average nearly $2 \%$ of the national forest area (Borsali et al., 2014).
Natural regeneration is predictable in some parts of the country, while in others, the conditions for recovery are not always favorable (Haddouche et al., 2006; Haddouche et al., 2011). As a result of repeated fires, pyrophyte vegetation develops on degraded soils and from which spontaneous regeneration of forest stands and reforestation are very difficult (Borsali et al., 2012). Monitoring of burnt forest areas has several objectives before, during and after the fire passage (Corona et al., 2008) and management of forest massifs necessarily involves the study and monitoring of spatio-temporal changes that have occurred in these areas. 
Application of remote sensing and GIS tools are widely used to locate priority intervention areas after forest fires; for example, to assess forests resilience (Arianoutsou et al., 2011) or to quantify and map post-fire erosion and runoff (Vafeidis et al., 2007). However, several authors (St-Pierre et al., 1991; Takaoka \& Sasa, 1996; Kalabokidis et al., 2012) used these tools to assess spatial distribution of post-fire regeneration.

Lardjem forest in the wilaya of Tissemsilt has not been spared by the fires that have occurred throughout recent years across the country. Our aim is to characterize the changes that have occurred in the forest after four years of the 2012 disastrous fire passage by analyzing satellite data acquired during periods 1987 and 2016, validated by field checks.

\section{MATERIALS AND METHODS}

\section{Study area}

The Lardjem forest is located about $30 \mathrm{~km}$ Northeast of Tissemsilt region (Fig. 1), and constitutes nearly $25 \%$ of the overall forest area of this wilaya (region). Although the vegetation cover contains various forest formations, it is mainly dominated by a dense stand by Aleppo pine Pinus halepensis Mill and wild Thuja Tetraclinis articulate (Vahl) Mast occupying slopes where the conditions

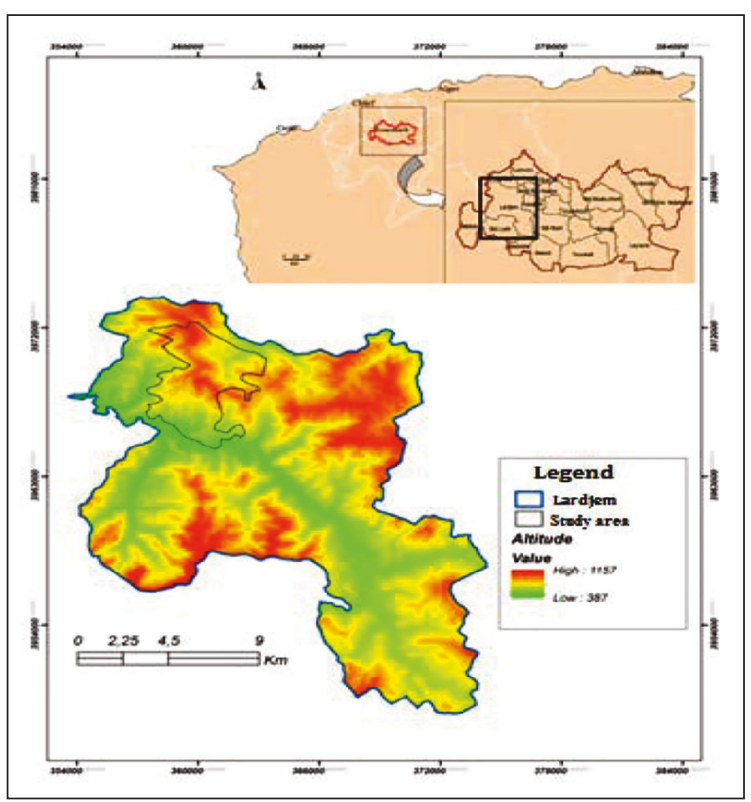

Figure 1. Location of the study area. are more favorable (Tir, 2015). The climate is Mediterranean with hot dry summer, marked by constraining conditions with strong seasonal variations and very clear irregularities of precipitation. A drought trend has been observed in this region since the 1980 , with a $25 \%$ decrease in cumulative annual precipitation and an increase of $0.7^{\circ} \mathrm{C}$ in average annual temperatures (Sarmoum, 2008).

\section{Data acquisition}

Two different Landsat 5 TM (1987) and Landsat 8 OLI / TIRS (2016) satellite images from Landsat satellites (Table 1) have been downloaded from the USGS (United States Geological Survey; www.usgs. glovis.com). The choice of acquisition date of the satellite images goes back to autumn period (September-October), this period is better suited to the approach based essentially on the analysis of the vegetation index sensitive to the presence of annual vegetation. According to Haddouche (2009) and Azzaoui et al. (2018), the contrast between annual and perennial vegetation, in the dry season, is the strongest and therefore the most detectable.

\section{Methodological approach}

A digital elevation model (DEM) is a representation of the topography, used for the extraction of geomorphological parameters (altitudes, slopes and exposures) of the study area. ENVI ${ }^{\circledR}$ and ArcGIS Software were used to extract slope, relief orientation (exposure) maps.

The treatment is carried out only on the areas covered by the fire in order to assess the state of vegetation recovery. To this effect, a mask representing the contours of the fire was applied to the map products to attenuate other regions not affected. The corresponding fire vector (2012) was explored in the field using Global Positioning System (GPS). Other information from surveys on field sites (geographic coordinates of some points, plant formations) were collected to validate the results of this study.

We used a vector file for the extraction of the study area for all the image scenes (1987 and 2016) as well as for the DEM (Fig. 2). The methodological approach adopted is essentially based on the analysis and interpretation of Normalized Difference Vegetation Index (NDVI) which is the ratio of the difference between the reflectance in the near infrared and in the red, on the sum of the two. 
The NDVI highlights the presence of the chlorophyllous activity of the vegetation, where it reflects a maximum of energy captured and recorded by the satellite sensor (Martin \& Chuvieco, 1995; Haddouche et al., 2011).

\section{RESULTS}

The first results of this work are maps of forest vegetation before and after the fire (between 1987 and 2016) (Fig. 3). These maps are the results of

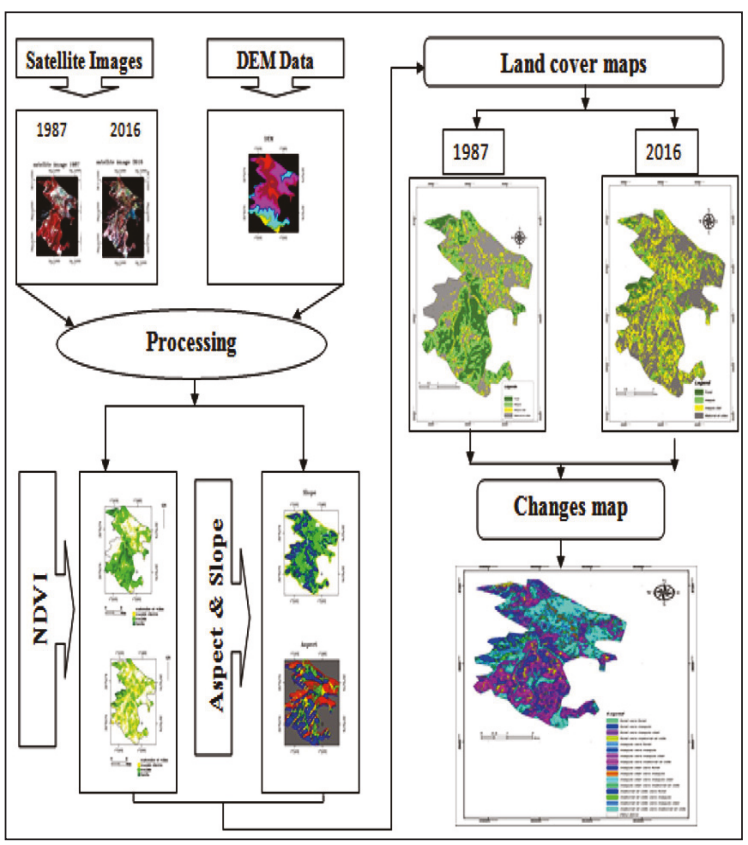

Figure 2. Organizational methodological scheme.

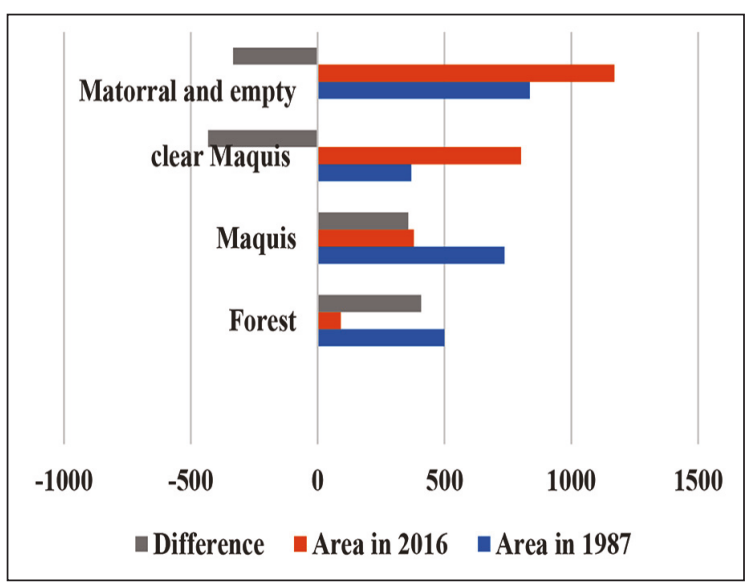

Figure 3. Evolution of each forest vegetation class (1987-2016). the NDVI interpretation by introducing a vegetation presence for each image. The final NDVI classification made it possible to group the different forest formations in the study area into four classes according to their presence and the degree of cover: matorral and empty area; clear maquis; dense maquis; forest (Fig. 4).

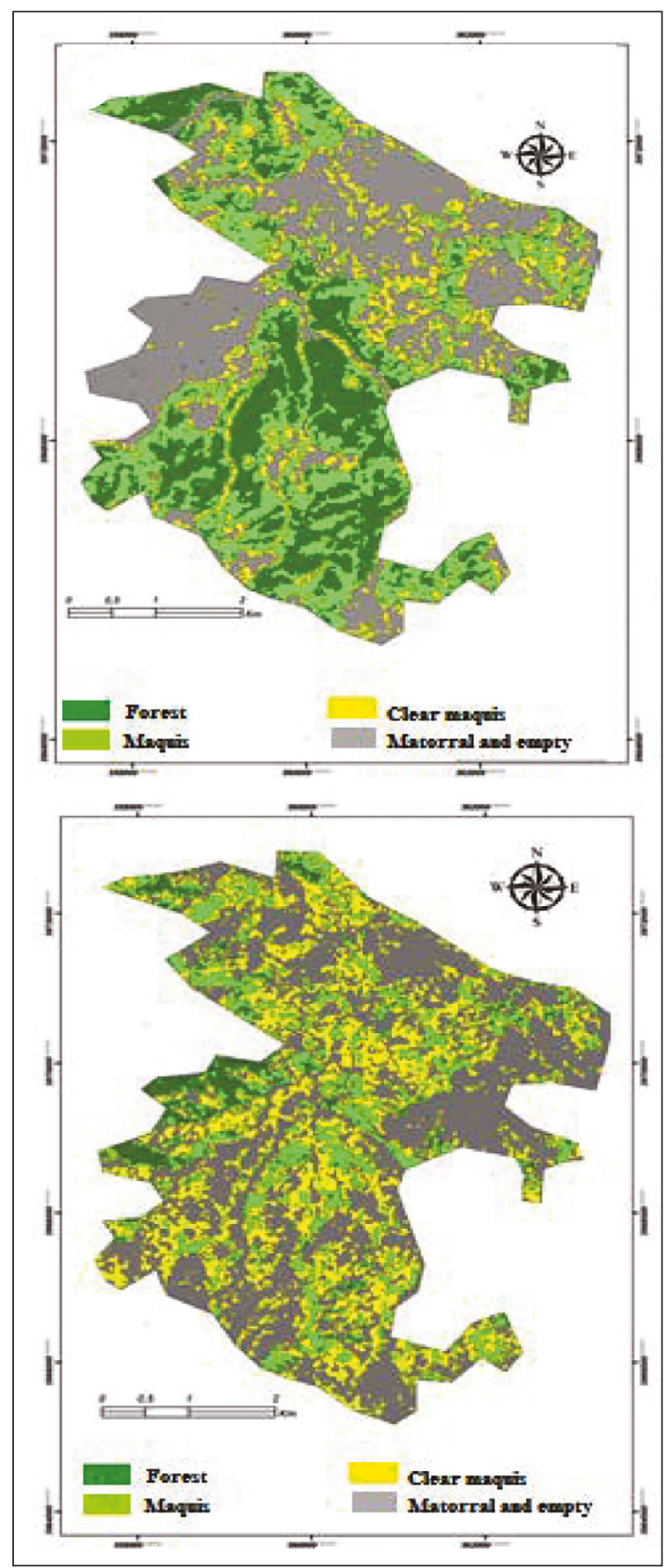

Figure 4. Maps of land occupation by forest vegetation (above: 1897; below: 2016). 


\begin{tabular}{|lccccc|}
\hline ID image & Sensor & $\begin{array}{l}\text { Acquisition } \\
\text { date }\end{array}$ & Resolution & $\begin{array}{c}\text { Bands } \\
\text { number }\end{array}$ & $\begin{array}{c}\text { Image size } \\
(\mathbf{K m})\end{array}$ \\
\hline LT51970351987291XXX03 & Landsat 5 TM & $18-10-1987$ & $30 \mathrm{~m}$ & 07 & $185 * 185$ \\
\hline LC81970352016259LGN00 & $\begin{array}{c}\text { Landsat } 8 \\
\text { OLI/TIRS }\end{array}$ & $15-09-2016$ & $30 \mathrm{~m}$ & 11 & $185 * 185$ \\
\hline
\end{tabular}

Table 1. Characteristics of the satellite images.

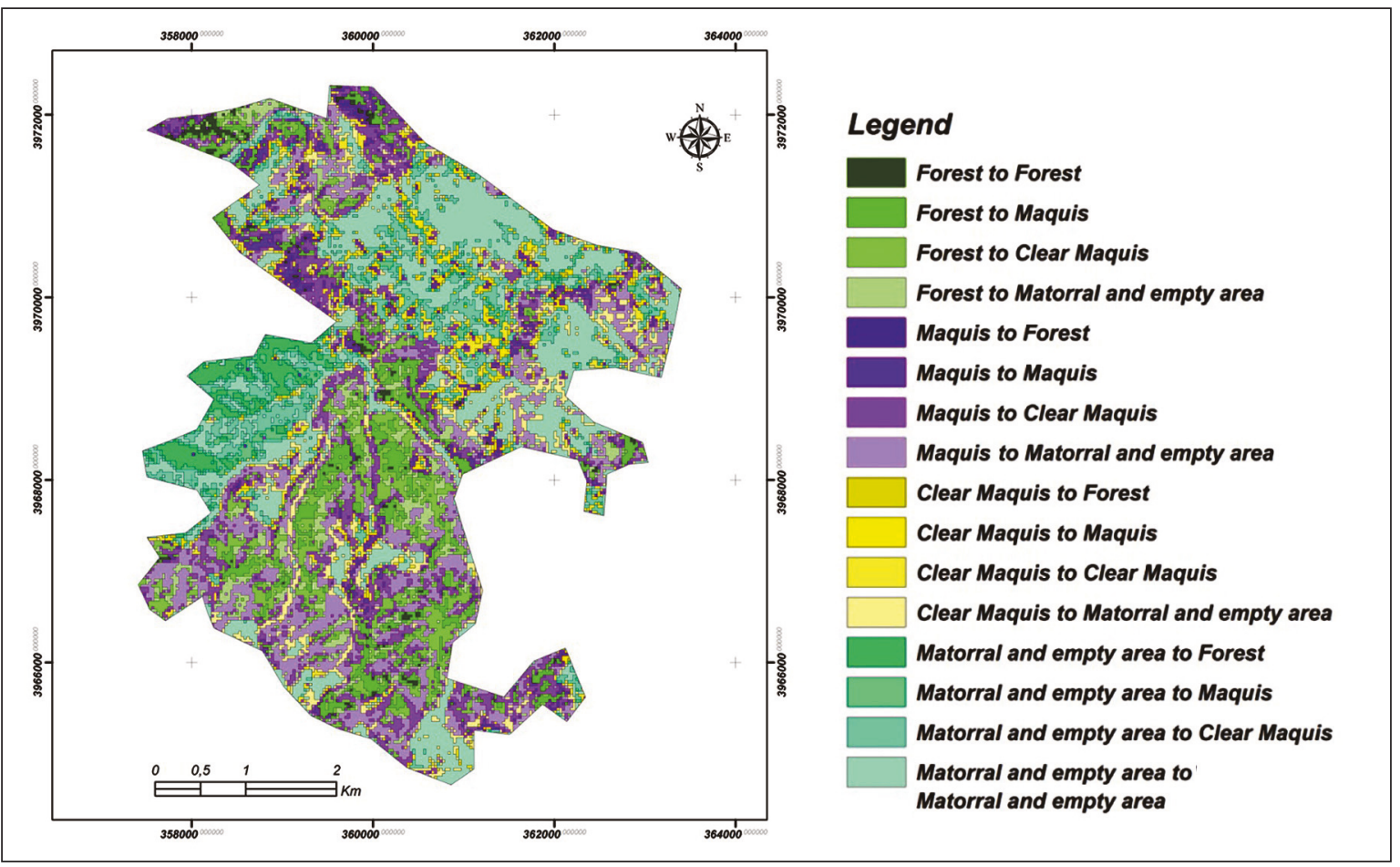

Figure 5. Changes map of the study area (1987-2016).

The results obtained (Figs. 3, 4) show a considerable reduction in plant cover. A loss of $81.72 \%$ in forest class area and $48.48 \%$ in maquis, compared to an increase of the clear maquis $117.11 \%$ and $39.83 \%$ empty area.

The characterization of changes occurring in the area of interest was made by crossing the two previous result maps in GIS, which made it possible to have the different mutations between the occupancy classes, and the map. Changes in forest cover are presented in Fig. 5.

\section{DISCUSSION}

The class-by-class analysis (Figs. 5, 6) shows that of the 499.77 ha of the forest class in 1987; 209.07 ha turned into clear maquis, 150.57 ha into maquis, 120.15 ha of matorral and empty and only 19.98 ha kept their appearance. Same for the maquis where 348.57 ha of 736.56 ha have transformed into matorrals and empty and 267.93 ha into clear maquis, while 108.54 ha remained maquis and 11.52 ha have become forests.

The clear maquis which were 369.18 ha in 1987 are also lost, with 187.38 ha transformed into matorral and empty, while 124.65 ha tkept their nature and 54 ha have become maquis and 3.15 ha transformed in forest. The matorral and empty class has preserved 513.72 ha of its area while the rest has seen an increase in plant cover.

In general, our results are in the same direction with those observed by Haddouche et al. (2011) which reveal a considerable reduction in plant cover and a clear decline in the forest class of the highest degree of cover. This is explained by the dominance 


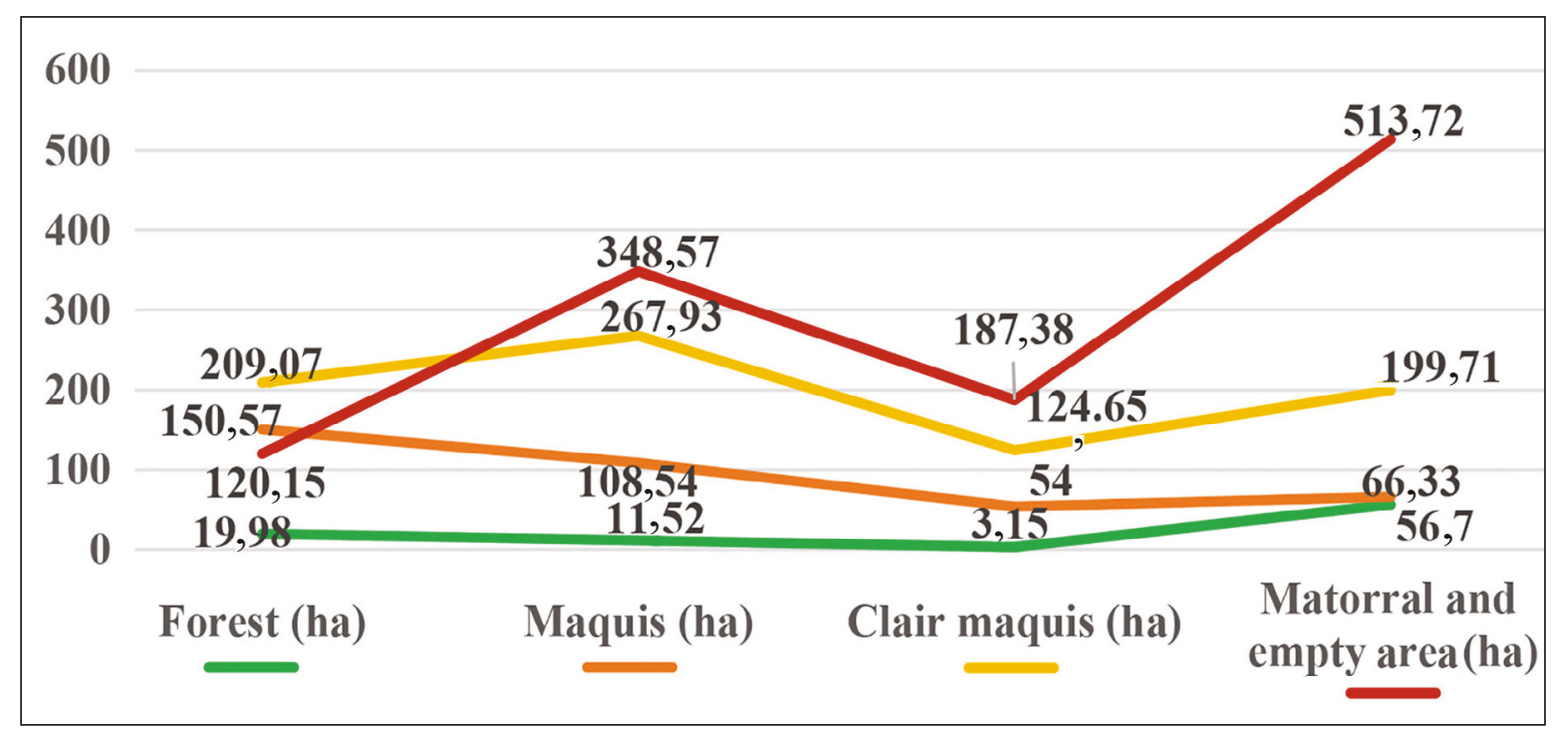

Figure 6. Evolution of the type of forest vegetation cover between 1987 and 2016.

of the Aleppo pine in the study area, known as active pyrophyte. According to Kuhnholtz-Lordat (1939) and Poirazidis et al. (2012), a species whose propagation, multiplication or reproduction is stimulated by fire and as reported (Boudy, 1955), the Algerian pine forests are the preferred lands for fires. Therefore, the action of fire on woody plants is very serious since it mutilates them in a disorderly manner to the point of often leading to their withering and death (Aubreville, 1950).

The low percentage that has recovered this class is due to the resilience of thuja to consecutive fires ensured by stump regeneration (Hadjadj \& Letreuch-Belarouci, 2017).

According to Bekdouche (2010), the shrubs occupy very little space during the first two years after the fire. The same author adds that this shrub layer reaches a significant recovery at 4 years after fires and a maximum post-fire recovery rate between 5 and 9 years old. This perfect adaptation finds its origin in the fact that the shrubs play an important positive role in the process of regeneration of the layers under shrub and herbaceous, in particular by the creation of a shelter which protects the young shoots from an excess of light and heat, trampling and herbivores (Pulido et al., 2010).

After the first years of the fire passage, a maximum number of species appear to be composed mainly by therophytes (Madoui et al., 2006) associated with a rapid natural regeneration of pine

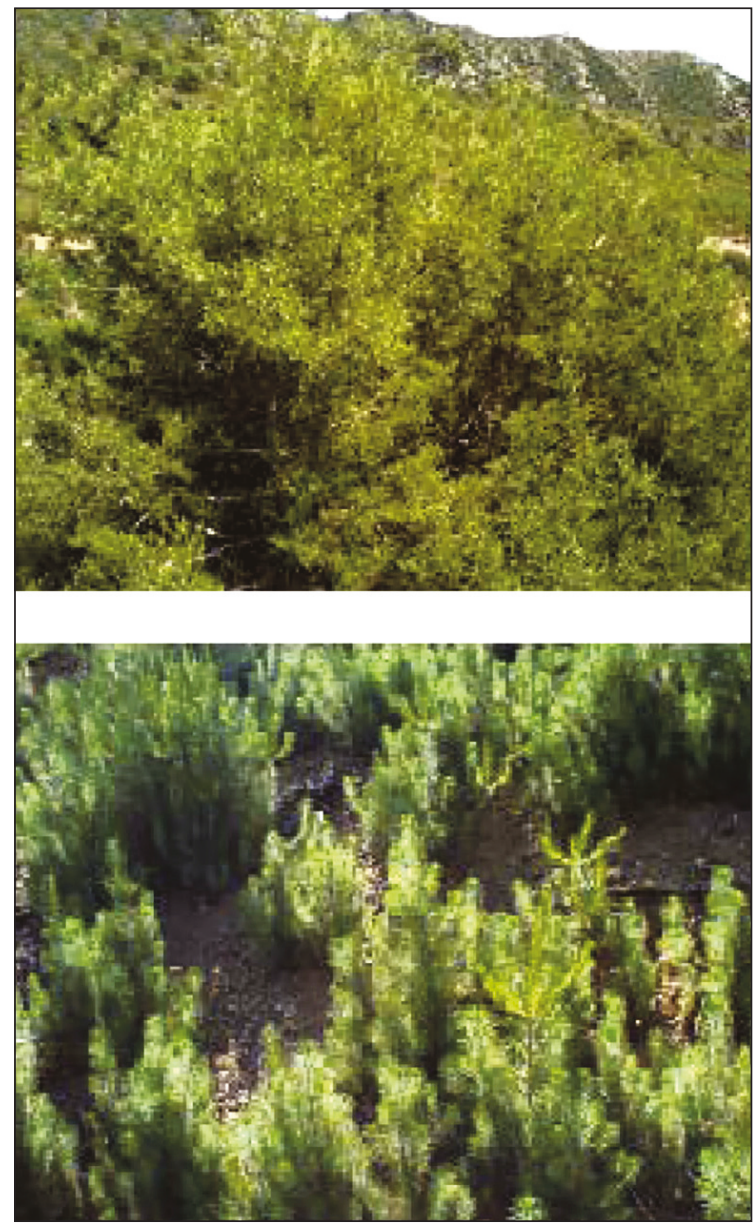

Figure 7. Post fire natural regeneration in the forest of Lardjem (above: Tetraclinis articulata (Vahl) Mast; below: Pinus halepensis Mill.) 
(Meddour, 1992) and other woody perennials with a great power of regeneration by vegetative way from strains such as wild Thuja, Tetraclinis articulata (Vahl) Mast, and holm oak (Quercus ilex L.). Howevwe, this form of regeneration is discreet and not quantifiable on Landsat satellite images, due to the moderate spatial resolution of the latter (Garah et al., 2016) which explains the increase in the area of the class of matorrals and empty spaces.

The observations made in the field show a different regeneration from one species to another. Tetraclinis articulata (Vahl) Mast shows the most significant growth which indicates the passage of fires, while Pinus halepensis Mill. shows a remarkable rate of regeneration in some places but growth remains slow (Fig. 7).

The morphology of the land also plays its role, as the regeneration of the two species and its growth rate are markedly better on the north-facing with weak slopes. In fact these slopes are more watered and receive cool winds to keep the wet soils, on the other hand, the south-facing slopes are sunnier and receive more heat, which causes the soil to dry out and consequently the conditions become unfavorable for plant recovery.

\section{CONCLUSIONS}

The use of satellite images makes it possible to provide direct assistance in the effectiveness of the intervention and to reduce the duration of prospecting in the field. After this bi-date case study, the concerns raised by the deforestation of many places in the Lardjem forest have given rise to several analyzes of the causes and effects of this situation.

Firstly, repetitive fires play a decisive role in the deterioration of the forest environment made from Aleppo pine (Pinus halepensis Mill.). Then comes the aridity of the climate which limits the natural regeneration due to the insufficiency and the irregularity of the rains, and finally the anthropozoogenic activities to worsen the situation.

For this purpose, managers must intervene to promote the natural regeneration of local species, especially in areas where conditions are favorable, to reforest areas with low regeneration; and to protect the environment from repetitive fires by establishing a forest fire plan for effective intervention in time and space.

\section{ACKNOWLEDGEMENTS}

The authors thank the DGRSDT for the financial support of this work.

\section{REFERENCES}

Arianoutsou M,. Koukoulas S \&. Kazanis D., 2011. Evaluating Post-Fire Forest Resilience Using GIS and Multi-Criteria Analysis: An Example from Cape Sounion National Park, Greece. Environmental Management, 47: 384-397. https://doi.org/10.1007/s00267-011-9614-7.

Aubreville A., 1950. Flore forestière soudano-guinéenne: AOF - Cameroun - AEF Société d'Editions Géographiques, Maritimes, et Coloniales, Paris.

Azzaoui M., Maamar B., Soudani L., Nouar B., Berreyah M. \& Maatoug M., 2018. Spatial dynamics of land cover in the Sdamas region (Tiaret, Algeria). Journal of Geology, Geography and Geoecology, 27: 12-19.

Bekdouche F., 2010. Evolution après feu de l'écosystème subéraie de Kabylie (Nord Algérien). Thèse de Doctorat en sciences agronomiques. Université de Tizi Ouzou, Algérie.

Borsali A.H.Banandeli K. \& Gros R., 2014. Dynamique structurelle de la végétation en zone semi-aride: cas de la forêt de Fénouane (monts de Saida, Algérie occidentale). Afrique Science, 10: 419-433.

Borsali A.H., Benabdeli K. \& Gros R., 2012. Reconstitution post incendie des propriétés physico-chimiques et microbiologiques de sols forestiers algériens (forêt de Fénouane, wilaya de Saïda). Ecologia mediterranea, 38: 59-73.

Boudy P., 1955. Economie forestière Nord-Africaine. Tome. 4, description forestière de l'Algérie et de la Tunisie. Editions Larose, Paris, 482 pp.

Corona P., Lamonaca A. \& Chirici G., 2008. Remote sensing support for post fire forest management. Forest-Biogeosciences and Forestry, 1: 6.

Garah K., Chafai C. \& Abdallah B., 2016. Évolution spatio-temporelle des écosystèmes forestiers à Pin d'Alep de l'Aurès oriental (Algérie). Revue forestière française, 68: 217-229.

Haddouche D., 2009. La télédétection et la dynamique des paysages en milieu aride et semi-aride en Algérie: cas de la région de Nâama. Thèse doctorat Universitè Tlemcen, Algérie, 259 pp.

Haddouche D. Benhanifia K. \& Hellal B., 2006. Utilisation de la télédétection pour l'étude de la déforestation. Cas de la région de Djelfa (Algérie). Revue Écologie-Environnement, 2: 1-14.

Haddouche D., Benhanifia K. \& Gacemi M., 2011. Analyse spatiale de la régénération forestière post-incendie 
de la forêt de Fergoug à Mascara, Algérie. Bois \& Forets des Tropiques, 307: 23-31.

Hadjadj K. \& Letreuch-Belarouci A., 2017. Synthèse bibliographique sur le thuya de berbérie [Tetraclinis articulata (Vahl) Mast.]. Geo-Eco-Trop, 41: 13-27.

Kalabokidis K., Xanthopoulos G., Moore P., Caballero D., Kallos G., Llorens J., Roussou O. \& Vasilakos C., 2012. Decision support system for forest fire protection in the Euro-Mediterranean region. European Journal of Forest Research, 131: 597. https://doi.org/10.1007/s10342-011-0534-0

Kuhnholtz-Lordat G., 1939. La terre incendiée. Essai d'agronomie comparée. Ed. Maison carrée.

Madoui A., 2002. Les incendies de forêt en Algérie Historique, bilan et analyse. Forêt méditerranéenne, 13: 23-30.

Madoui A., Gehu J.M. \& Alatou D., 2006. L'effet du feu sur la composition des pinèdes de Pinus halepensis Mill. Ecologia mediterranea, Revue international d'écologie méditerranéenne, 32: 5-13.

Martin M.P. \& Chuvieco E., 1995. Mapping and evaluation of burned land from multitemporal analysis of AVHRR NDVI images. EARSeL Advances in Remote Sensing, 4 : 7-13.

Meddour R., 1992. Régénération naturelle de Cedrus atlantica Man et de divers pins après incendie dans l'arboretum de Meurdja (Algérie). Forêt méditerranéenne, 13: 275-287.

Meddour-Sahar O., Meddour R. \& Derridj A., 2008. Analyse des feux de forêts en Algérie sur le temps long (1876-2007). Les Notes d'analyse du CIHEAM, 39.

Meddour-Sahar O. \& Bouisset C., 2013. Les grands incendies de forêt en Algérie: problèmes humains et politiques publiques dans la gestion des risques. Méditerranée, 121: 33-40.

Missoumi A., Mederbal K. \& Benabdelli K., 2002. Apport des Systèmes d'information géographiques dans la prévention et la lutte contre les incendies de forêts.
Exemple de la forêt domaniale de Kounteidat, Algérie. Forêt méditerranéenne, 13: 11-22.

Poirazidis K.S., Zografou K., Kordopatis P., Kalivas D.P., Arianoutsou M., Kazanis D. \& Korakaki E., 2012. A GIS-based integrated approach predicts accurately post-fire Aleppo pine regeneration at regional scale. Annals of Forest Science, 69: 519-529.

Pulido F., García F., Obrador E. \& Moreno G., 2010. Multiple pathways for tree regeneration in anthropogenic savannas: incorporating biotic and abiotic drivers into management schemes. Journal of Applied Ecology, 47: 1271-1281.

Sarmoum M., 2008. Impact du climat sur le dépérissement du cèdre de l'Atlas. Diagnostic climatique et dendroécologique de la cédraie de Theniet El Had. Thèse de magister, USTHB, Algérie, 98 pp.

St-Pierre H. Gagnon R. \& Bellefleur P., 1992. Régénération après feu de l'épinette noire (Picea mariana) et du pin gris (Pinus banksiana) dans la forêt boréale, Québec. Canadian Journal of Forest Research, 22: 474-481.

Takaoka S. \& Sasa K., 1996. Landform effects on fire behavior and post-fire regeneration in the mixed forests of northern Japan. Ecological Research, 11: 339349.

Talbi O., Benabdeli K., Benhanifia K. \& Haddouche D., 2017. Cartographie des zones de risque de feux de forêt dans la commune de Doui Thabet, Saïda, Algérie, International Journal of Environmental Studies, https://doi.org/10.1080/00207233.2017.1386434

Tir E., 2015. Analyse spatiale et cartographie de la régénération forestière post-incendie dans la Wilaya de Tissemsilt. Mémoire de Magister, Université Aboubakr Belkaïd -Tlemcen (Algérie), 87 pp. http://dx.doi.org/10.13140/RG.2.2.19303.78249

Vafeidis A.T., Drake N. \& Wainwright J., 2007. A proposed method for modelling the hydrologic response of catchments to burning with the use of remote sensing and GIS. CATENA, 70: 396-409. 
